\title{
Studies on the acid attack resistance of sugarcane bagasse fibre geopolymer concrete
}

\author{
Thandra Arun ${ }^{1}, T$. Srinivas ${ }^{2}$, N.V.Ramana $\mathrm{Rao}^{3}$ \\ ${ }^{1}$ P.G.Student, GRIET, Hyderabad, India. \\ ${ }^{2}$ Professor, GRIET, Hyderabad, India. \\ ${ }^{3}$ Professor, JNTUH, Hyderabad, India
}

\begin{abstract}
It is necessary to reduce the effect of carbon dioxide, as failure to do so will result in global warming. In this instance, researchers have begun looking for sustainable building materials. Industrial byproducts like flyash, GGBS, silica (SiO2) are used to make geopolymer concrete. To produce binders alkali liquids can be used to react with aluminate, silica and with flyash, alkali activated concrete is made by mixing binders with coarse and fine particles and forming a mixture.. In addition to this concrete sugarcane bagasse fibres is added to improve the properties of concrete. The main objective of this paper is to study the durability properties in terms of like acid attack resistance on sugarcane bagasse fibre reinforced geopolymer concrete (GPCF) of G40 equivalent M40 when it is exposed to $5 \%$ acids attack with the help of experiments. The test specimens were casted and then cured in an oven at $60^{\circ} \mathrm{C}$ for 24 hours after one day rest period. The test specimens were kept at room temperature for the remainder of the time. After 28 days, the specimens were immersed in acids such as HCL and H2SO4 for 15,45 , and 75 days before being tested according to codal procedures on the 15 th, 45th, and 75th days, and the results were compared to controlled concrete (CC), sugarcane bagasse fibre reinforced controlled concrete (CCF), and geopolymer concrete (GPC)). From the results it is observed that CCF and GPCF showed more resistant than CC and GPC when it is subjected to acids attack.
\end{abstract}

\section{Introduction}

The problem of sulphuric and hydrochloric acid corrosion in concrete sewer pipes has been recognized, but it has not been totally remedied. To prevent this issue, a superior alternative to acid-resistant regular Portland cement-based concretes can be made by substituting extra elements in part. To increase controlled concrete's long-term performance in acidic conditions binder is required to res ${ }^{1}$ ist the sulphuric acid and hydrochloric acid. Geopolymer binders are novel binders that depends on alumina silicate. By using of byproducts from industries, this will reduce not only the consumption of standard Portland cement, but also the manufacture of cement, as well as the emission of greenhouse gases. which leads to sustainable environment. Sugarcane bagasse fibres are

\footnotetext{
*Corresponding Author: srinu.tummala@gmail.com
}

the byproducts from sugarcane industry, which is a dry residue after the sugarcane stalks are crushed to obtain juice. . Throughout the country, there are several thermal power stations. so flyash is abundantly available. Sodium silicates and sodium hydroxide are alkaline solutions which are cheaply available. From the past literatures the polymerization process is fast at 60 to 90 degree centigrade. During the summer, in india during summer the temperature is above 30 degree centigrade. Geopolymer concrete that cures naturally at room temperature is known as curing free concrete. The focus of this research is to determine acid attack resistance in terms of weight loss of CC, $\mathrm{CCF}, \mathrm{GPC}$, and GPCF of various concretes exposed to $5 \% \mathrm{HCL}$ and $\mathrm{H} 2 \mathrm{SO} 4$ concentrations.

\section{Materials}

\subsection{Ordinary Portland cement}


Ordinary Portland cement with a grade of 53 is utilised in the experiments. Physical characteristics of the cement were examined in accordance with IS:40311968.

\subsection{Fine aggregate}

The fine aggregate used is sourced locally. It is devoid of contaminants. organic pollutants, silt, and clay matter. Physical properties tests were conducted like fineness modulus, gradation, bulk density and specific gravity. Fine aggregate has a specific gravity of 2.63.

\subsection{Coarse aggregate}

In this investigation, crushed aggregate with a maximum size of $20 \mathrm{~mm}$ was procured from local crusher plants. Physical properties of coarse aggregate, such as bulk density, flakiness, elongation index, and bulk density, were tested. It is determined that coarse aggregate has a specific gravity of 2.61 .

\subsection{Flyash}

Class $\mathrm{F}$ flyash is in present study of work. Taken from the local sources that is RMC plant which is bolaram, Hyderabad.

\subsection{Ground Granulated Blast Furnace Slag}

A byproduct of the steel industry is ground granulated blast furnace slag. It is defined as a nonmetallic product made up of calcium silicates and other bases that is formed in a blast furnace when iron is molten.

Table1.Physical Properties of GGBS

\begin{tabular}{|l|l|}
\hline Characteristics & Result \\
\hline Colour & Dull white \\
\hline Fineness (Blaine" $\mathrm{s}) \mathrm{m}^{2} / \mathrm{kg}$ & 450 \\
\hline Specific Gravity & 2.91 \\
\hline Glass content percent & 93 \\
\hline Bulk Density $\mathrm{kg} / \mathrm{m}^{3}$ & 1100 \\
\hline
\end{tabular}

\subsection{Water}

According to IS:456:2000, it must be free of contaminants such as chemicals, oils, and other types of pollutants when mixing concrete.

\subsection{Sodium Hydroxide}

It is one of the major ingredient in geopolymer concrete. Sodium hydroxide pellets are procured from local the local laboratory and the following are the specifications.

Table2. Specifications of $\mathrm{NaOH}$

\begin{tabular}{|l|l|}
\hline Molar mass & $40 \mathrm{gm} / \mathrm{mol}$ \\
\hline Appearance & White solid \\
\hline Density & $2.1 \mathrm{gr} / \mathrm{cc}$ \\
\hline Melting point & $318^{0} \mathrm{c}$ \\
\hline Boiling point & $1390^{\circ} \mathrm{cc}$ \\
\hline
\end{tabular}

\subsection{Sodium silicate}

Sodium silicate plays an important role in polymerization process. It is a type of alkaline liquid. Following are the specifications of sodium silicate.

\begin{tabular}{|l|l|}
\hline Specific gravity & 1.57 \\
\hline Molar mass & $123.06 \mathrm{gm} / \mathrm{mol}$ \\
\hline $\mathrm{Na} 2 \mathrm{O}$ (by mass) & $15.35 \%$ \\
\hline $\mathrm{SiO} 2$ (by mass) & $30.00 \%$ \\
\hline Water (by mass) & $56.00 \%$ \\
\hline Weight ratio (SiO2 to $\mathrm{Na} 2 \mathrm{O}$ ) & 2.09 \\
\hline Molarity ratio & 0.98 \\
\hline
\end{tabular}

\subsection{Super plasticizer}

As a water-reducing additive, Sulphonated Napthalene Formaldehyde was utilised, which increases the workability of concrete.

\subsection{Sugarcane bagasse fibre}

Sugarcane bagasse is a byproduct from sugarcane industry. It is a residue after the sugarcane stalks or sorghum stalks are crushed to extract the juice. Aspect ratio of fibre is 66.7 .

\section{Experimental Investigation}

\subsection{General}


The primary goal of this work is to report results from a study of low calcium flyash and slag-based sugarcane bagasse fibre reinforced geopolymer concrete exposed to $5 \%$ acid solutions for up to 2.5 months of G40, which is equivalent to M40. An alkaline solution is made up of sodium hydroxide and sodium silicate. Because the highest compressive strengths are at these ratios, the ratios of $\mathrm{Na} 2 \mathrm{SiO} 3$ to $\mathrm{NaOH}$ are 2.5 and $\mathrm{SiO} 2$ to $\mathrm{Na} 2 \mathrm{O}$ are 2.09 . The $100 \mathrm{mmX} 100 \mathrm{mmX} 100 \mathrm{~mm}$ cubes were cast, and after one day, the test specimens were cured in an oven at 60 degrees Celsius for 24 hours in the case of geopolymer concrete, and the specimens were ambient cured for the rest of the time. After 28 days, the specimens were immersed in acids such as H2SO4 and HCL for 15, 45, and 75 days, respectively, to determine the acid attack resistance of $\mathrm{CC}, \mathrm{CCF}, \mathrm{GPC}$, and sugarcane bagasse fibre reinforced geopolymer concrete exposed to $5 \%$ concentrations of H2SO4 and HCL in terms of weight loss and compressive strength. Acid durability and attack factors of $\mathrm{CC}, \mathrm{CCF}, \mathrm{GPC}$, and $\mathrm{GPCF}$ concretes exposed to a $5 \%$ concentration of $\mathrm{HCL}$ and $\mathrm{H} 2 \mathrm{SO} 4$ are also assessed to determine their acid resistance.

\subsection{Mixing and casting of geopolymer concrete.}

The geopolymer concrete was made in the same way as regular concrete. Flyash, GGBS, sugarcane bagasse fibre concrete, and aggregates were combined for three minutes under dry conditions before adding the alkaline liquid (Sodium silicate and sodium hydroxide) mixed with superplasticizer to the dry mixture and mixing for another four minutes. The workability of concrete is then assessed using a standard slump test. Fresh concrete is poured and compacted in the same way that controlled concrete is.

\section{Test Results}

\subsection{Weight loss and Residual compressive strength}

The concretes CC, CCF, GPC and GPCF of specimens are exposed to $5 \%$ of $\mathrm{HCL}$ and $\mathrm{H} 2 \mathrm{SO} 4$ solutions. For both the acids HCL and H2SO4, it is seen that the loss of compressive strength and weight rises as the immersion period increases.

Table1.Weight loss in percentage when immersed in HCL solution.

\begin{tabular}{|c|c|c|c|c|}
\hline & $\begin{array}{c}\text { Weights } \\
\text { before } \\
\text { immersion }\end{array}$ & \multicolumn{3}{|c|}{ Weights after immersion } \\
\hline CC & 2.44 & 2.28 & 2.22 & 2.2 \\
\hline $\begin{array}{c}\text { \% of } \\
\text { weight } \\
\text { loss }\end{array}$ & & & & \\
\hline CCF & 2.37 & 2.22 & 2.18 & 2.15 \\
\hline $\begin{array}{c}\text { \% of } \\
\text { weight } \\
\text { loss }\end{array}$ & & 5.22 & 8.71 & 9.82 \\
\hline GPC & 2.23 & 2.14 & 2.08 & 2.07 \\
\hline $\begin{array}{c}\text { \% of } \\
\text { weight } \\
\text { loss }\end{array}$ & & & & \\
\hline GPCF & 2.42 & 2.35 & 2.26 & 2.29 \\
\hline $\begin{array}{c}\% \text { of } \\
\text { weight } \\
\text { loss }\end{array}$ & & & & \\
\hline \multicolumn{2}{|c|}{} & 2.77 & 6.25 & 5.17 \\
\hline
\end{tabular}

Table2.Weight loss in percentage when immersed in $\mathrm{H} 2 \mathrm{SO} 4$ solution.

\begin{tabular}{|c|c|c|c|c|}
\hline & $\begin{array}{c}\text { Weights } \\
\text { before } \\
\text { immersion }\end{array}$ & \multicolumn{3}{|c|}{ Weights after immersion } \\
\hline & & $\mathbf{1 5}$ & $\mathbf{4 5}$ & $\mathbf{7 5}$ \\
\hline CC & 2.44 & 2.31 & 2.23 & 2.20 \\
\hline $\begin{array}{c}\% \text { of } \\
\text { weight } \\
\text { loss }\end{array}$ & & & & \\
\hline CCF & 2.37 & 2.25 & 2.2 & 2.17 \\
\hline $\begin{array}{c}\% \text { of } \\
\text { weight } \\
\text { loss }\end{array}$ & & 4.82 & 7.15 & 8.26 \\
\hline GPC & 2.23 & 2.15 & 2.11 & 2.09 \\
\hline $\begin{array}{c}\text { \% of } \\
\text { weight } \\
\text { loss }\end{array}$ & & & & \\
\hline GPCF & 2.42 & 2.37 & 2.29 & 2.31 \\
\hline $\begin{array}{c}\% \text { of } \\
\text { weight } \\
\text { loss }\end{array}$ & & & & \\
\hline
\end{tabular}




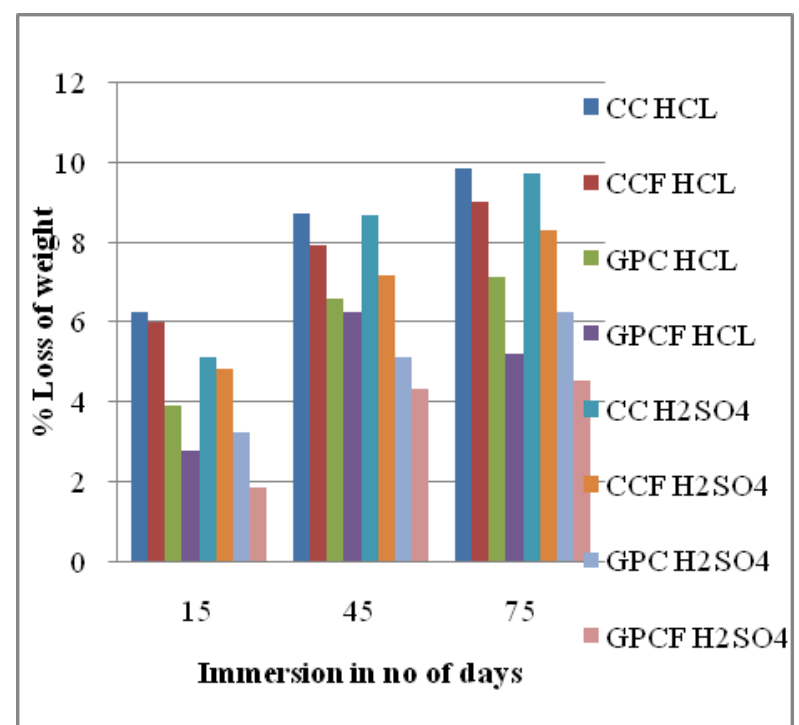

Fig.1. When concrete is immersed in 5\% concentrations of various acids, losses of weight in percentages..

Table3.Compressive strength loss in percentage when immersed in HCL solution.

\begin{tabular}{|c|c|c|c|c|}
\hline & $\begin{array}{c}\text { Strength } \\
\text { before } \\
\text { immersion }\end{array}$ & \multicolumn{3}{|c|}{ strength after immersion } \\
\hline & & $\mathbf{1 5}$ & $\mathbf{4 5}$ & $\mathbf{7 5}$ \\
\hline CC & 49.2 & 46.69 & 46.07 & 45.64 \\
\hline $\begin{array}{c}\text { \% of } \\
\text { strength } \\
\text { loss }\end{array}$ & & 5.11 & 6.36 & 7.22 \\
\hline CCF & 55.3 & 52.62 & 51.97 & 51.55 \\
\hline $\begin{array}{c}\text { \% of } \\
\text { strength } \\
\text { loss }\end{array}$ & & 4.86 & 6.02 & 6.77 \\
\hline GPC & 50.5 & 48.55 & 47.81 & 47.45 \\
\hline $\begin{array}{c}\text { \% of } \\
\text { strength } \\
\text { loss }\end{array}$ & & 3.86 & 5.32 & 6.05 \\
\hline GPCF & 56.8 & 55.17 & 53.92 & 53.55 \\
\hline $\begin{array}{c}\text { \% of } \\
\text { strength } \\
\text { loss }\end{array}$ & & & & \\
\hline
\end{tabular}

Table4.Compressive strength loss in percentage when immersed in $\mathrm{H} 2 \mathrm{SO} 4$ solution.

\begin{tabular}{|c|c|c|c|c|}
\hline & $\begin{array}{c}\text { Strength } \\
\text { before } \\
\text { immersion }\end{array}$ & \multicolumn{3}{|c|}{ strength after immersion } \\
\hline & & $\mathbf{1 5}$ & $\mathbf{4 5}$ & $\mathbf{7 5}$ \\
\hline CC & 49.2 & 46.28 & 45.69 & 44.64 \\
\hline $\begin{array}{c}\text { \% of } \\
\text { strength } \\
\text { loss }\end{array}$ & & 5.92 & 7.12 & 9.26 \\
\hline CCF & 55.3 & 52.41 & 51.86 & 50.88 \\
\hline $\begin{array}{c}\text { \% of } \\
\text { strength } \\
\text { loss }\end{array}$ & & 5.22 & 6.22 & 7.98 \\
\hline GPC & 50.5 & 48.37 & 47.72 & 47.2 \\
\hline $\begin{array}{c}\text { \% of } \\
\text { strength } \\
\text { loss }\end{array}$ & & 4.23 & 5.51 & 6.52 \\
\hline $\begin{array}{c}\text { GPCF } \\
\text { \% of } \\
\text { strength } \\
\text { loss }\end{array}$ & 56.8 & 54.63 & 54.01 & 53.44 \\
\hline
\end{tabular}

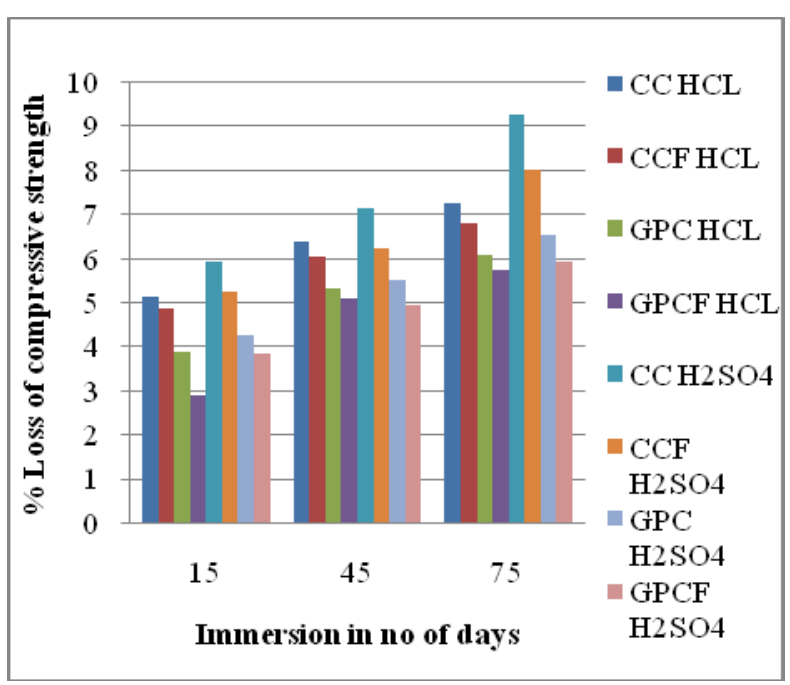

Fig.2.Compressive strength Loss in Percentage of concretes when immersed in 5\% concentrations of various Acids. 
Table5.Acid Durability factors and Acid Attack Factors when immersed in HCL solution.

\begin{tabular}{|c|c|c|c|}
\hline & \multicolumn{3}{|c|}{ Acid durability factor } \\
\hline & \multicolumn{3}{|c|}{ HCL } \\
\hline & $\mathbf{1 5}$ & $\mathbf{4 5}$ & $\mathbf{7 5}$ \\
\hline CC & 18.97 & 56.18 & 92.76 \\
\hline CCF & 19.03 & 56.38 & 93.21 \\
\hline GPC & 19.34 & 56.80 & 93.96 \\
\hline GPCF & 19.42 & 56.95 & 94.27 \\
\hline
\end{tabular}

\begin{tabular}{|c|c|c|c|}
\hline & \multicolumn{3}{|c|}{ Acid attack factor } \\
\hline & \multicolumn{3}{|c|}{ HCL } \\
\hline & 15 & 45 & 75 \\
\hline CC & 0.10 & 0.40 & 0.63 \\
\hline CCF & 0.05 & 0.20 & 0.42 \\
\hline GPC & 0.00 & 0.11 & 0.22 \\
\hline GPCF & 0.00 & 0.05 & 0.13 \\
\hline
\end{tabular}

Table6.Acid Durability factors and Acid Attack Factors when immersed in $\mathrm{H} 2 \mathrm{SO} 4$ solution.

\begin{tabular}{|c|c|c|c|}
\hline & \multicolumn{3}{|c|}{ Acid durability factor } \\
\hline & \multicolumn{3}{|c|}{ H2SO4 } \\
\hline & $\mathbf{1 5}$ & $\mathbf{4 5}$ & $\mathbf{7 5}$ \\
\hline CC & 18.81 & 55.71 & 90.73 \\
\hline CCF & 18.95 & 56.26 & 91.74 \\
\hline GPC & 19.16 & 56.69 & 93.46 \\
\hline GPCF & 19.63 & 57.05 & 94.08 \\
\hline
\end{tabular}

\begin{tabular}{|c|c|c|c|}
\hline & \multicolumn{3}{|c|}{ Acid attack factor } \\
\hline & \multicolumn{3}{|c|}{ HCL } \\
\hline & 15 & 45 & 75 \\
\hline CC & 0.12 & 0.47 & 0.69 \\
\hline CCF & 0.06 & 0.31 & 0.45 \\
\hline GPC & 0.00 & 0.12 & 0.26 \\
\hline GPCF & 0.00 & 0.06 & 0.11 \\
\hline
\end{tabular}

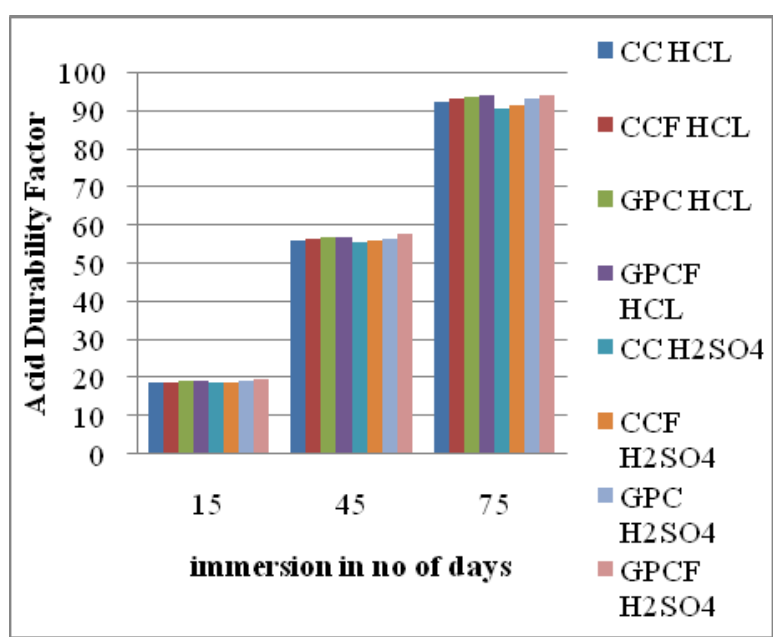

Fig.3. Acid Durability Factors of concretes when immersed in $5 \%$ concentrations of various Acids.

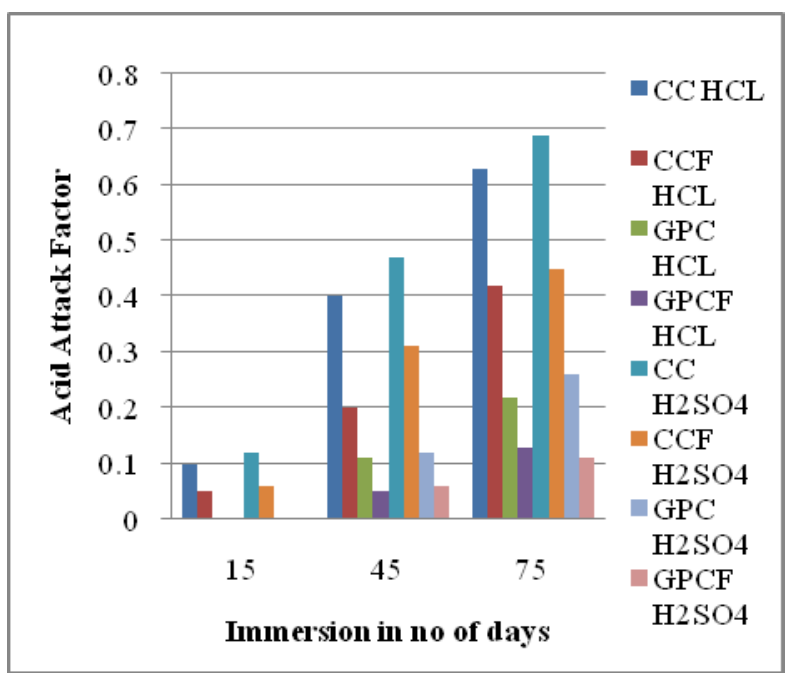

Fig.3. Acid Attack Factors of concretes when immersed in $5 \%$ concentrations of various Acids.

\section{Conclusions:}

From the current investigation, the following particular conclusions can be drawn:

1. For all concretes, the percentage loss of weight and compressive strength increases when the specimens are subjected to sulphuric acid and hydrochloric acid.

2. The loss of compressive strength of CCF and GPCF decreased by $6.23 \%$ and $5.61 \%$ respectively when it is compared with CC and GPC under hydrochloric acid attack for a period 75 days. 
3. The loss of compressive strength of $\mathrm{CCF}$ and GPCF decreased by $13.82 \%$ and $11.80 \%$ respectively when it is compared with $\mathrm{CC}$ and GPC under sulphuric acid attack for a period 75 days

4. The loss of weight of CC is more than that of other concretes and the loss of weight of GPCF is less than other.

5. In terms of Acid Attack Factors, GPCF is less attacked and more resistant to Acid Durability Factors than the other three concretes.

6. Because sulphuric acid causes more strength loss than hydrochloric acid, it is argued that the sulphuric acid environment is more severe.

\section{References}

1. Francisco Hernandez-Olivares, Rosa Elizabeth Medina-Alvarado, Xavier Eduardo Burneo-Valdivieso, Alonso Rodrigo ZunigaSuarez, Const and Bui. Materials, 247, 118451 (2020).

2. Ankur Laxman Yadav, V. Sairam, L. Muruganandam, K. Srinivasan, Jou. of Cleaner Production, 245,118854, (2020)

3. Shubha Vinaya A.S, Sachitha H.D ,Ravindra M.L,Darshan P,Lakshmi P.S. Int. Journal of Engg. Research in Mech and Civil Engineering, 05, 8 (2020)

4. Karthik Rao, R., Bobba, P.B., Suresh Kumar, T., Kosaraju, S. Materials Today: Proceedings, 26, pp. 3085-3089, 2019

5. Dr. V.M. Sounthararajan, Int. Journal of Civil Engg and Tech, 9, 10 (2018)

6. Arun kumar Jha, Anil Sanodiya, Rakesh Rathor. Int. Journal of Emerging Tech in Engineering Research, 6, 1 (2018)

7. T.Srinivas and M. Abinay Raj, Int. J. of Eng.and Adv. Tech. (IJEAT), ISSN: $2249-$ 8958, Volume-8 Issue-6 (2019)

8. T.srinivas and P. Manoj Anand, Int. J. of Innov. Tech. and Explor. Eng.g (IJITEE), ISSN: 2278-3075, Volume-8 Issue-12 (2019)

9. T.Srinivas and G. Sukesh Reddy, Int. J. of Eng.and Adv. Tech. (IJEAT), ISSN: $2249-$ 8958, Volume-9 Issue-1 (2019)

10. T.Srinivas and R. N. Koushik, Int. J. of Innov. Tech. and Explor. Eng.g (IJITEE), ISSN: 2278-3075, Volume-8 Issue-12 (2019), PP 112-117.

11. K. Sai Gopi, Dr. T. Srinivas and S. P. Raju V,
E3S Web of Conferences ICMED 184, 01084GRIET, 28-29 February, https://doi.org/10.1051/e3sconf/20201 $\underline{84011084}(2020)$

12. Jagannadha Kumar, M.V., Jagannadha Rao, K., Dean Kumar, B., Srinivasa Reddy, V., Int. J. of Civil Eng. and Tech., 9(7), pp. 11331141 (2018)

13. Ganta, J.K., Seshagiri Rao, M.V., Mousavi, S.S., Srinivasa Reddy, V., Bhojaraju, C., Structures 28, pp. 956-972 (2020)

14. Naidu, K.S.S.T., Rao, M.V.S., Reddy, V.S., Int. J. of Innov. Tech. and Explor. Eng.g (IJITEE), 8(9 Special Issue 2), pp. 641-642 (2019)

15. Chandana Priya, C., Seshagiri Rao, M.V., Srinivasa Reddy, V., Int. J. of Civil Eng. and Tech., 9(11), pp. 2218-2225 (2018)

16. Satya Sai Trimurty Naidu, K., Seshagiri Rao, M.V., Srinivasa Reddy, V., Int. J. of Civil Eng. and Tech., 9(11), pp. 2383-2393 (2018)

17. Supriya, Y., Srinivasa Reddy, V., Seshagiri Rao, M.V., Shrihari, S., Int. J. of Rec. Tech. and Engi., 8(3), pp. 5381-5385 (2019)

18. Kotkunde, N., Krishna, G., Shenoy, S.K., Gupta, A.K., Singh, S.K. International Journal of Material Forming, 10 (2), pp. 255-266 (2017)

19. Srinivas Rao J, S K Tummala, Kuthuri N R, Indonesia Journal of Electrical Engg. \& Computer Science, 21 (723), 2020

20. Govardhan, D., Kumar, A.C.S., Murti, K.G.K., Madhusudhan Reddy, G. Materials and Design, 36, pp. 206-214. (2012)

21. Kumar, P., Singhal, A., Mehta, S., Mittal, A. Journal of Real-Time Image Processing, 11 (1), pp. 93-109. (2016)

22. Raghunadha Reddy, T., Vishnu Vardhan, B., Vijayapal Reddy, P. International Journal of Applied Engineering Research, 11 (5), pp. 3092-3102 (2016)

23. Hussaini, S.M., Krishna, G., Gupta, A.K., Singh, S.K. Journal of Manufacturing Processes, 18, pp. 151-158 (2015)

24. Adhitya Satriawan Raharjo, Ilham Kurniawan, Gifary Maulana W, Yosi Noviari W, Sasmita Purwa H, Machsus Fawzi, Ridho Bayuaji. Asian Jou. of Applied Sci, 05, 4, 2017.

25. Dr.T Srinivas ,Dr. N V Ramana Rao, Int. Jou. of Civil Engineering and Tech. 10, 02, (2019). 